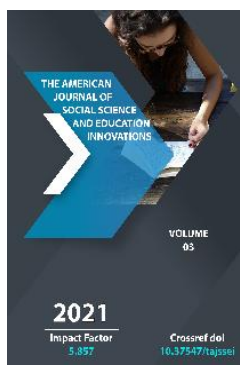

\title{
Artistic Image And Nationality
}

\author{
Abduvakhob Kayumov \\ Senior Researcher, Doctor Of Philosophy In Philology, (PhD), Department Of Uzbek Language \\ And Literature, Fergana State University, Uzbekistan
}

Journal Website:

http://usajournalshub.c om/index,php/tajssei

Copyright: Original content from this work may be used under the terms of the creative commons attributes 4.0 licence.

\section{ABSTRACT}

The article explores the national features of Paulo Coelho's The Alchemist and Isajon Sultan's The Free. The course of events and philosophy of both works are close to each other. The dream-goal of the protagonists is given in a similar way to the images of the journey process. Therefore, the symbolic meanings in the images, in the way of expression of ideas, in the materials that reveal the subject, in some artistic details are analyzed from a national point of view. In this work, the role and importance of the novels "Alchemist" and "Free" in the education of a harmoniously developed person is revealed. Also, the artistic skills and unique styles of the writers were studied.

\section{KEYWORDS}

Nationality, identity, spiritual perfection, symbolism, universality, harmonious person, theme, idea, image, detail, national content, national character.

\section{INTRODUCTION}

Literary influence contributes to the improvement and development of the national literature of nations. Although the themes and ideas, events and protagonists of some works are very similar to each other, they differ in the method of expression, symbolic images, 
national identity. As the well-known writer Chingiz Aytmatov noted: "Every literature strives for universal content while standing on the national soil"[1]. Paulo Coelho's "The Alchemist" and Isadjan Sultan's "Free" are such works that originated in the "national land."

\section{MAIN PART}

These novels state that "Self-awareness is the main and royal theme not only of literature, but of all human life"[2]. In the novel "Free", the main character, Ozod sets out in search of his luck, love and happiness. The reasons for going on a trip, like the heroes of folklore, stem from national identity. What he sees and learns during the journey leads him to spiritual perfection. In The Alchemist, Santiago sets out in search of treasure. In this play, the dream is taken as a vehicle for the protagonist to set out on a journey. In both novels, there is symbolism in everything the protagonists encounter along the way, and they act as coaches. This method is somewhat reminiscent of mystical ways. At the end of the stages of mysticism, a person is expected to reach the Truth and realize his identity. The protagonists of the above novels also understand existence and identity at the end of events. They reach the level of valuing and valuing things, beings, events and themselves in the whole universe. However, the works differ in a number of aspects, such as compositional structure, plot tactics, symbolism in images and details, national identity.

\section{RESULTS AND DISCUSSIONS}

In defining the nationality of the novel "Free", the phrase "peculiarities of the Uzbek people" is a bit narrow. Because the novel is imbued with universal ideas specific to the East. In many places, in addition to the national features of the Uzbek people, attempts have been made to shed light on the thoughts of the whole world, the oriental character, by quoting from the works of our writers and poets.

The Alchemist also draws attention to the national characteristics of the peoples in the description of the events that took place in Andalusia, Africa and Egypt. In Santiago's conversation with her parents, in the thoughts of Fatima, a desert girl, the peculiarities are even more vividly depicted in the images of the china. Through the national imagery, "the bitter truths of life, the strict school, which educates, heals, and even transforms man into a great sage, are artistically based"[3].

In both plays, the protagonists go on a journey. National features are highlighted in the images of the departure process. In particular, the legend of the tulip among the people in the novel "Free" is the basis for the trip. The essence of this narration is known to the villagers. The neighborhood is not indifferent to Ozod's upbringing. Therefore, all those who met Ozod on the way wished him a safe journey: "May your path be clear," said the owner of the vineyards.[2]

Also, in Uzbekistan, children do not leave their parents' control and upbringing, both at a young age, in adulthood and in adulthood. In turn, children are always the parents respect the national feature. This is evident in the fact that it is constantly remembered and analyzed by Ozod.

Santiago's journey begins a little differently. It is known that in some European nations, a child's freedom is guaranteed when he or she grows up. A similar situation is observed in the life of Santiago. After attending seminary until the age of sixteen, he discusses a travel plan with them that is not in line with his parents 
'dream. After much arguing, his father allows him. After that, in other places, the image of the parent does not appear again, nor is it remembered by Santiago. It is, as noted above, that the freedom in children acquires a national appearance as the formation of individualism. Due to the strong socialization of our people, Ozod pays a lot of attention to national images of respect for parents.

There are also some peculiarities in the treatment of women depicted in the novels. In the life and literature of the Uzbek people, it is important that a person's true love is focused on only one person. In the novel Ozod, the above idea is taken into account in the symbols of Eran and Dilorom, Ozod and Aydin. In the novel "The Alchemist", Santiago falls in love with two girls (Movuchi's daughter and Fatima). The writer may not have shed light on the movuchin's love for his daughter. But the issue of freedom of love in the peoples of Latin America is also unique. It is also seen in several places in the work that beautiful women are paralleled with the concept of homeland: "Buy a flock of sheep and go around the world until you realize that our castle is the most important castle in the world and there are no more beautiful women than our women"[4].

From the repetition of such an image several times during Santiago's conversation with his father, it is clear that in Paulo Coelho's country, beautiful women acquire nationality as one of the symbols of the Homeland.

There are a number of similarities and differences in the interpretation of the images of Dilorom, Aydin and Fatima in the novels. All are described as smart, polite, loyal, imaginative girls. The places in the novel "Ozod" depicting the meeting between Eran and Dilorom, the boundaries of life are the most elegant nationality of our people, a sign of beauty and originality in Uzbek girls:

"As I was saying this, I wanted to take him by the hand ... and he took a straw and threw it on the ground.

"There's a border in the middle," he said. - It is impossible to pass., The world will collapse"[2].

A similar picture can be found in The Alchemist:

"Santiago came to the girl's hands holder, but Fatima stood firmly cling to his eyes with one hand,"[4].

Only here the concept of pitcher modesty does not reflect the limits of modesty in a bright national image like "one straw". Because the jug is a common item in most nations, it does not retain a distinct national character.

In fact, Fatima is no less moral than Dilorom. It shows the wisdom, patience, courage and freedom of a desert girl. But in some places, their freedom gives rise to feelings of freedom: "Their bodies are connected for the first time. Santiago hugged the girl”.[4]

In both novels, the inmates acted as a means, a cause, to guide the young men on their journey. Also, their image is illuminated as a symbol of aryat, wise, thoughtful, patient friends.

When attention is paid to the essence of the novels, all the features necessary for a person to grow up in society are taken into account. Respect for parents, relationships with the land, attention to humanity, animals, the environment are described. "Any aesthetic phenomenon that occurs on a particular ground remains a sign of the aspects relevant to that condition"[5] . In accordance with this 
theory, the writers enrich the national content of the work. In The Alchemist, the symbolic meanings of sheep, wind, falcon, snake, crystal vessels, ehroms, urim, and tummim stones perform more ideological functions than other details used in the play. They serve Santiago's spiritual perfection, self-realization, acquaintance with the world, harmony with the world. The novel "Free" also has deep meanings in such symbolic details as tulips, wind, trees, birds, horses, lions, turtles, scorpions, dogs, creatures, lakes, salt deserts. The details used by both writers speak in their own languages, that is, they promote universal ideas while expressing the national concepts specific to their peoples. The wind is one of the leading characters in the novels and is represented in Isadjan Sultan as a symbol of wisdom, high power, a guide, a companion, a teacher who helps to unravel the essence of mysteries. In "The Alchemist" it is given as the king of the desert, mainly as a symbol of power. The wind also helps the heroes to reconcile with the universe, to understand that man, beings, are a part of Allah. The captain of the tribes in the desert with a discussion of Santiago into the wind, and as a result of "the power of God, who"[4] understands the stained. Ozod ascended to the "end of the heights"[2, 156] with the help of the wind, to Allah.

In the novel "The Alchemist", a person who realizes his national identity realizes that he is a symbolic wind, that is, one with the Truth: "The boy was absorbed in the Spirit of the Universe and saw that the Spirit of the Universe is a part of the Spirit of God and the Spirit of God is his own soul. And he is able to perform miracles"[4].

Ozod also concludes: "I have started to feel the force of the wind in my body! O Lord of the worlds, Lord of men, creator of events, coach of life! I have mastered the wisdom of the rain! Now I can go back like the wind and rain on my land? ... now I can turn to dust and scatter the treasures inside me on my land ?! ... Now I am gathering water and fire, air and dust, ... now I understand who I am"[2].

\section{CONCLUSION}

The expression in national lines of the means necessary for the harmonious upbringing of a person, regardless of nationality or race, is raised in the novels "Free" and "Alchemist" as universal problems. The stages of human development are covered with the help of national background, national details, national characters. The process of development of the heroes as a harmoniously developed person is described in terms of form and content on the basis of national, essentially universal ideas. Due to these qualities, these novels have a right to take an eternal place in the treasury of universal works in the formation and education of a harmoniously developed person with national spirituality.

\section{REFERENCES}

1. Rahimjonov Numan. Understanding man // Literature and art of Uzbekistan // Gazeta. May 22, 2015.

2. Sultan Isadjan. Free: Novels and stories. $T$ $\therefore$ - Sharq, 2012. P.429.

3. Davronova Shohsanam. Literary influence and originality // Uzbek language and literature // Journal. Issue 5 Tashkent, 2015. P.73-78.

4. Paulo Coelo. Alchemist. Roman. New Age Generation, 2013. b. 180.

5. Yuldash Kazakboy, Yuldash Mukhayyo. Fundamentals of artistic analysis. Tashkent: Kamalak, 2016. P.462. 
The American Journal of Social Science and Education Innovations (ISSN - 2689-100x)

6. Khushbokov Jovli, Isadjan Sultan. Conversation. If the prayer of the hand is lucky // Literature and art of Uzbekistan // Issue 31. July 29, 2016.

7. Abdurashidovich K. A. Motivation and National Character of Foolishness in Uzbek Literature //ANGLISTICUM. Journal of the Association-Institute for English Language and American Studies. - 2018. T. 7. - №. 4. - C. 47-51.

8. Qayumov A. CREATING OF A NATIONAL CHARACTER THROUGH MEANS OF LITERATURE //Theoretical \& Applied Science. - 2018. - №. 1. - C. 235-240.

9. Qayumov A. NATIONALITY: YESTERDAY AND TODAY //Конференции. - 2020.

10. Sabirdinov A. ASKAR KASIMOV IN THE UZBEK POETRY OF THE XX CENTURY THE ROLE AND IMPORTANCE OF CREATION //Конференции. - 2020.

11. SABIRDINOV A. Sketches to the novel "Night and day" by Chulpan //Scientific journal of the Fergana State University. 2019. - T. 1. - №. 6. - C. 119-120.

12. Gafurovich S. A. Analysis Of The Poem" Autumn Dreams" By Abdulla Oripov //The American Journal of Social Science and Education Innovations. - 2021. - T. 3. - №. 01. - C. 556-559.

13. Abdupattoev M. T. Unusual Connections As Forming Literary Text //The American Journal of Social Science and Education Innovations. - 2021. - T. 3. - №. 02. - C. 177182.

14. Abdurakhmonova, M. M., ugli Mirzayev, M. A., Karimov, U. U., \& Karimova, G. Y. (2021). Information Culture And Ethical Education In The Globalization Century. The American Journal of Social Science and Education Innovations, 3(03), 384388.
15. Mannopov I. S. THE ISSUE OF AUTHORSHIP OF THE POETICS IN DIVANI HIKMAT //Theoretical \& Applied Science. 2020. - №. 9. - C. 411-414.

16. Sultonalievich M. I. YASSAVI LITERATURE AND ITS EMERGENCE /IANGLISTICUM. Journal of the Association-Institute for English Language and American Studies. 2020. - T. 9. - №. 8. - C. 26-33.

17. Oripova, G. (2019). UZBEK POETRY AND THE WORLD LITERATURE IN THE YEARS OF INDEPENDENCE. Scientific Journal of Polonia University, 32(1), 116-120.

18. Oripova Gulnoza Murodilovna. (2019). THE PECULIARITIES OF VAZN METER IN UZBEK POETRY OF THE INDEPENDENCE PERIOD. International Journal of Anglisticum. Literature, Linguisitcs and Interdisciplinary Studies. Volume: 8 /Issue:2/. - Macedonia, 2019. -P.33-39.

19. Murodilovna O. G. Melody and musicality in Lirycs //ACADEMICIA: An International Multidisciplinary Research Journal. - 2020. - T. 10. - №. 11. - C. 656-664.

20. Karimov, U., \& Abdurakhmon, A. (2017). INNOVATIVE INFORMATION TECHNOLOGY IN EDUCATION. Форум молодых ученых, (5), 9-12.

21. Oripova G. M., Tolibova M. T. Q. Composition of Modern Uzbek Stories //The American Journal of Social Science and Education Innovations. - 2021. - T. 3. №. 03. - C. 245-249.

22. Каримов, У., \& Каримова, Г. (2018). ГЕОПОЛИТИЧЕСКАЯ КОНКУРЕНЦИЯ В ИНФОРМАЦИОННОМ ПРОСТРАНСТВЕ. In Перспективные информационные технологии (ПИТ 2018) (рр. 1368-1372).

23. Akhmadjonova O. A. Symbolic And Figurative Images Used In The Novel "Chinar" //The American Journal of Social 
Science and Education Innovations. - 2021.

- T. 3. - №. 03. - C. 389-392.

24. Каримов, У. У. (2017). РОЛЬ СРЕДСТВ МАССОВОЙ ИНФОРМАЦИИ В ПРОЦЕССЕ ГЛОБАЛИЗАЦИИ. In Перспективные информационные технологии (ПИТ 2017) (рр. 1189-1192).

25. Каримов, У., Хакимова, Д., \& Тулкинов, 3. (2018). ЗАДАЧИ ПОСТРОЕНИЯ ГРАЖДАНСКОГО ОБЩЕСТВА. Теория и практика современной науки, (10), 193195.

26. Normatova D. E. PECULIARITIES OF ANTHROPOCENTRISM AND HUMANISM OF THE SOCIO-PHILOSOPHICAL THOUGHT OF WESTERN EUROPE IN THE ERA OF RENAISSANCE //Scientific Bulletin of Namangan State University. - 2019. - T. 1. - №. 5. - C. 168-173.

27. Mukhammadjonova Guzalkhan. The image of a creative person in the poetry of Erkin Vohidov. ACADEMICIA: An International Multidisciplinary Research Journal. Volume : 10, Issue : 11, November. - India, 2020.

28. Mashrapova, G. (2020, December). A UNIQUE IMAGE IN THE STORIES OF SHUKUR KHOLMIRZAYEV. In Конференции

29. Mashrapova, G. A. (2021). The Role Of Narrator In The Structure Of The Artistic Fiction. The American Journal of Social Science and Education Innovations, 3(03), 378-383

30. Oripova, G. (2020, December). RHYTHM AND MYTHING IN LYRICAL GENRE. In Конференции. 